\title{
Health risk implications from simultaneous exposure to multiple environmental contaminants
}

\author{
B. Genthe ${ }^{\mathrm{a},(*)}$, W.J. Le Roux ${ }^{\text {b }}$, K. Schachtschneider ${ }^{\text {a }}$, P.J. Oberholster ${ }^{\mathrm{a}, \mathrm{c}}$, N.H. Aneck-Hahn ${ }^{\mathrm{d}}$, J. Chamier ${ }^{\mathrm{a}}$ \\ ${ }^{a}$ Council for Scientific and Industrial Research, Natural Resources and the Environment, PO Box 320, Stellenbosch 7599, South Africa ${ }^{\mathrm{b}}$ Council for Scientific and Industrial Research, \\ Natural Resources and the Environment, PO Box 395, Pretoria 0001, South Africa \\ ${ }^{\mathrm{c}}$ Department of Paraclinical Sciences, Faculty of Veterinary Science, University of Pretoria, P/Bag X04, Onderstepoort 0110, South Africa ${ }^{\mathrm{d}}$ EDC Laboratory, Department of \\ Urology, University of Pretoria, PO Box 667, Pretoria 0001, South Africa
}

\section{A B S T R A C T}

Water quality has deteriorated in the upper Olifants River system, South Africa, as a result of land use activities which include mining, agriculture and industries. A health risk assessment was conducted from 2009 to 2011 in the catchment to determine the possible risks local communities face from various pollutants such as microbials, heavy metals and oestrogen in the river water and vegetation. Aluminium and manganese accumulated in plants and vanadium and aluminium concentrations found in selective water samples posed significant health risks when consumed. A quantitative microbial risk assessment revealed that the combined risk of infection ranged from 1 to 26 percent with the Norovirus posing the overall greatest health risk. The anticipated disability adjusted life years resulting from drinking untreated water from these sites are in the order of 10,000 times greater than what is considered acceptable. The oestradiol activity, caused by endocrine disrupting compounds in the water, measured above the trigger value of 0.7 ng $\mathrm{L}^{-1}$. Impoverished communities in the area, who partially depend on river water for potable and domestic use, are exposed to immune-compromising metals that increase their probability of infection from waterborne diseases caused by the excess microbial pathogens in the contaminated surface water.

\section{Keywords:}

Heavy metals

Oestradiol

Human health

Microbial

pathogens Water

quality

\section{Introduction}

The Olifants River has been described as one of the most polluted rivers in southern Africa because of the impacts from various water and land use practices in the catchment (Oberholster et al., 2010). Coal mining, coal-fired power stations, industrial activities and agricultural practices, combined with a general decline in the efficiency of wastewater treatment facilities, have all contributed to a steady decline in water quality in the catchment. Many studies have shown that phytoplankton com-munities (Oberholster et al., 2010), fish species (Watson et al., 2012) and crocodile populations (Ashton, 2010) are being affected by the mixture of acid mine drainage and increased nutrient levels present in the Olifants River system. Guidelines to evaluate the quality of drinking water are unsuited for monitoring untreated river water, as authorities do not consider river water as drinking water. Unfortunately in South Africa poor rural communities can be exposed to the untreated river water either because of lack of services or through accidental exposure. There is currently a

\footnotetext{
${ }^{(*)}$ Corresponding author. Fax: +27 218882682

E-mail address: bgenthe@csir.co.za (B. Genthe).
}

knowledge gap in translating observed impacts on water quality and ecosystem health into possible human health risks as well as the implications of multiple threat exposure. Water has become increasingly contaminated by microbial pathogens, heavy metals and other chemical pollutants which include endocrine disrupting compounds (Oberholster, 2011). Health risks associated with polluted water include infectious diseases, acute or chronic chemical toxicity and carcinogenicity, amongst others.

Microbial pathogens present in untreated river water can cause serious diseases in humans. Among the most common waterrelated infectious diseases are gastroenteritis, amoebiasis, salmonellosis, dysentery, cholera, typhoid fever, hepatitis-A and diarrhoea (Andersson and Bohan, 2001). The World Health Organization (WHO) estimates that 88 percent of deaths caused by diarrhoeal disease are attributable to unsafe water supply and poor sanitation and hygiene (World Health Organization, 2004). Pathogens (including opportunistic pathogens) are introduced into the aquatic environment typically by surface and subsurface runoff, wildlife excrement, septic tank systems and urban runoff including storm water and sewage spills (Ksoll et al., 2007; Field and Samadpour, 2007).

Continued mining, industrial and power generation activities in the Olifants River catchment have led to a general acidification of 
the water system and the input and mobilisation of heavy metals (Oberholster et al., 2010; Hobbs et al., 2008). Elevated levels of heavy metals in an aquatic ecosystem pose a significant threat to aquatic life and ultimately to human health, reaching considerable concentrations in plants and biota through bioaccumulation. Heavy metals are of particular significance in ecotoxicology because of their high degree of persistence, and all have the potential to be toxic to living organisms (Dyer and Belanger, 1999; Rashed, 2010; Nagajyoti et al., 2010) above threshold concentra-tions. Endocrine disrupting compounds (EDCs) are substances that can mimic or interfere with the hormonal and homoeostatic systems which regulate a variety of biological functions including development, behaviour, fertility and normal cell metabolism (Crisp et al., 1998; World Health Organization and International Program on Chemical Safety, 2002; Miyamoto and Burger, 2003). Reduced fertility, increased cancer risk (Soto and Sonnenschein, 2010) and increases in spontaneous abortions have been linked to elevated concentrations of EDCs in the environment (Robins et al., 2011). The major sources of these compounds in surface waters are from pesticides, agricultural runoff (Pedersen et al., 2003; Rahman et al., 2009; Ternes et al., 1999) and wastewater treatment plant effluent. In South Africa, varying concentrations of EDCs, more specifically oestrogen mimicking compounds, have been found in surface water and wastewaters (Aneck-Hahn et al., 2009; Bornman et al., 2007; Slabbert et al., 2007). The most recent (2011) audit of municipal wastewater treatment works in South Africa, presented in the so-called "Green Drop report" (Department of Water Affairs, South Africa, 2011), found that of the 821 facilities evaluated, 143 (17 percent) were performing poorly and 317 (39 percent) were in a critical condition.

It is for these reasons that there is a need to monitor and assess microbial and chemical contaminants in the upper Olifants River catchment. This will lead to a better understanding of the associated risks to human health and the management thereof. In this study, a quantitative health risk assessment is provided that affords a means of estimating the probability of adverse effects associated with the levels of hazardous elements found in the Olifants River water. The health risk assessment also serves as a tool for predicting the extent of the combined potential or probable health effects in the catchment. The methodology fol-lowed is described by the USEPA (U.S. Environmental Protection Agency, 1987; U.S. Environmental Protection Agency, 1992) and the WHO (World Health Organization, 2010), and is divided into four steps namely (a) hazard identification, (b) dose response assess-ment, (c) exposure assessment and (d) risk characterisation. The study focuses on the health risks associated with human con-sumption of the river water through drinking and ingestion of plants exposed to the microbial, heavy metal and oestrogen mimicking compounds detected in the river water at various locations in the catchment. The results of this study can serve as a baseline for other catchments with similar land uses and possible risks posed to the local communities.

\section{Materials and methods}

2.1. Study area

Fifteen sites were selected along the Olifants River for the collection of water and plant samples. The sampling site positions are shown in Fig. 1 and the various stressors impacting on each of the sites is listed in Table 1. For the purposes of this study, the stressors were limited to those which directly impact on water quality. Potential indirect stressors, such as the impact of atmospheric deposition from coalfired power station emissions, were excluded because of the difficulty in quantifying the impact from such a diffuse source on river water quality.

\subsection{Sample collection}

Surface water samples were collected on a monthly basis over a period of one year. Duplicate samples (one for metals and microbial pathogen analysis and the other for EDC analysis) were collected at each site in pre-acid washed 1-litre glass Schott bottles. Water samples for EDC analysis were adjusted to a $\mathrm{pH}$ of 3 by adding

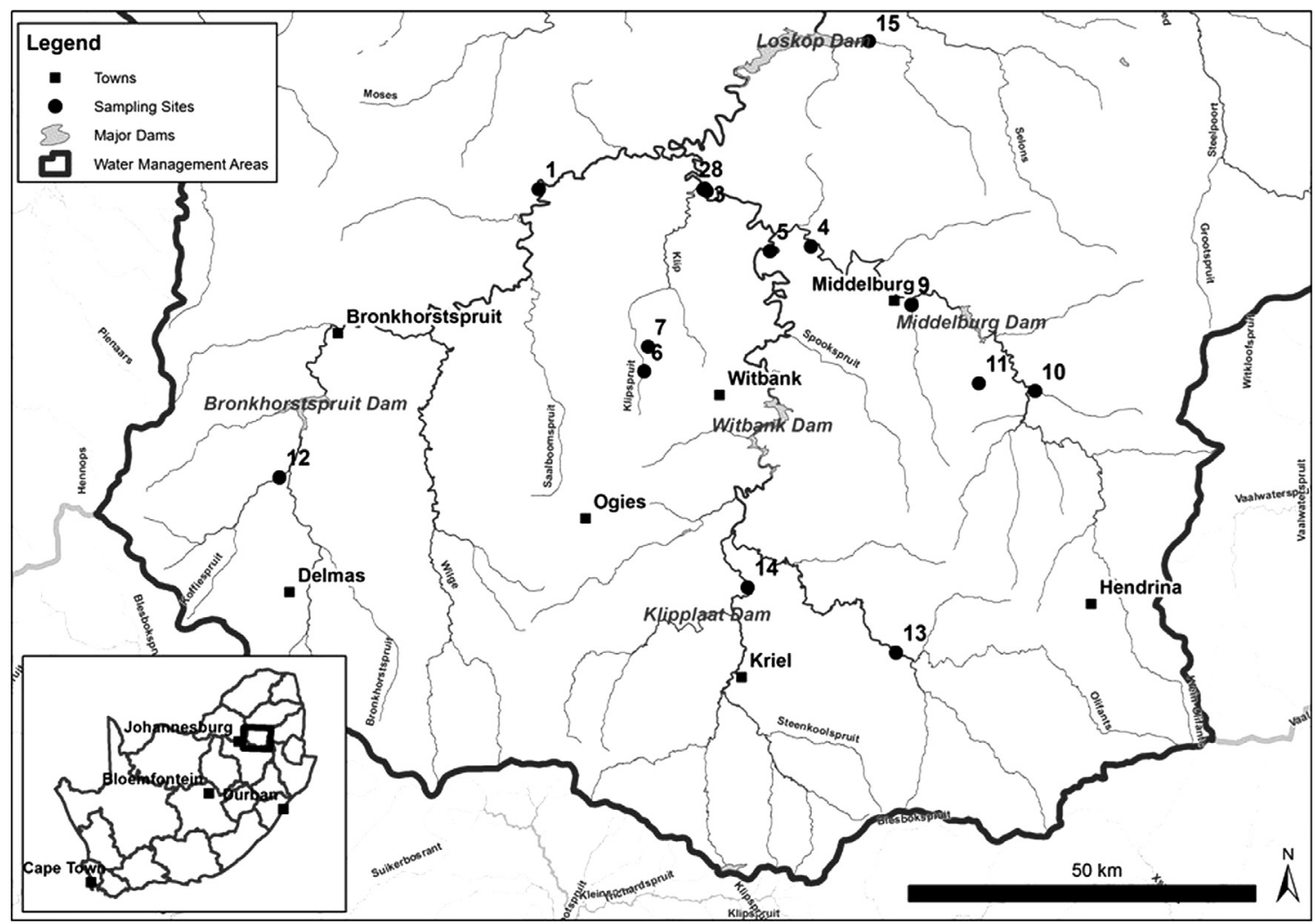

Fig. 1. Location of the 15 sampling sites along the Olifants River (South Africa) selected for health risk assessment from exposure to contaminated river water. 
sulphuric acid. The water samples were stored at $4{ }^{\circ} \mathrm{C}$ in the period between collection and delivery to the analytical laboratory and analysis, where after extracted samples were stored at $-20^{\circ} \mathrm{C}$.

The plant species selected for evaluation were collected from the riparian vegetation bordering on wetlands in the Olifants River. Wetlands acts as natural filters, removing metals and nutrients from the river water (Schachtschneider et al., 2010). Plants collected from this region will therefore serve as higher level bioaccumulation indicators. Riparian vegetation species, Phragmites australis, Typha capensis and Cynodon dactylon were sampled by separately placing $5 \mathrm{~g}$ of fresh shoot and root material into labelled HDPE sample tubes and refrigerating the material until analysis. Plant material was washed five times with Millipore de-ionised water before metals analysis. The modified XP1500 method and inductively coupled atomic emission spectrometry were used to analyse for metals in the plant tissue.

\subsection{Microbial analysis}

Escherichia coli (E. coli) was used as an indicator of faecal contamination. Three bacterial pathogens (Salmonella sp., Vibrio cholerea and Shigella sp.), two protozoan parasites (Gardia sp. and Cryptosporidium sp.) and two enteric viruses (Enterovirus and Norovirus) served the purpose of pathogen monitoring for microbial health risk assessment.

For E. coli, the determination was made using the IDEXX Colilert ${ }^{\mathrm{TM}}$ Most Probable Number (MPN) method carried out according to the manufacturer's

Table 1

Land use stressors causing the main impacts on water quality at each of the sampling sites along the Olifants River.

\begin{tabular}{llllll}
\hline & Agriculture & Industrial & Mining & Sewage effluent & Feedlots \\
\hline Site 1 & $\times$ & & & $\times$ & \\
Site 2 & & $\times$ & $\times$ & $\times$ & \\
Site 3 & $\times$ & $\times$ & $\times$ & $\times$ & \\
Site 4 & $\times$ & $\times$ & $\times$ & $\times$ & \\
Site 5 & $\times$ & $\times$ & $\times$ & $\times$ & \\
Site 6 & & $\times$ & $\times$ & \\
Site 7 & & $\times$ & $\times$ & $\times$ & \\
Site 8 & $\times$ & $\times$ & & $\times$ & \\
Site 9 & & & & & \\
Site 10 & & & & & \\
Site 11 & & & & & \\
Site 12 & $\times$ & & & & \\
Site 13 & $\times$ & & & & \\
Site 14 & $\times$ & & & & \\
Site 15 & $\times$ & & & & \\
\hline
\end{tabular}

protocol. All pathogen cells were harvested from their individual broths, and DNA extracted using InstaGene Matrix (Biorad Technologies). Salmonella sp. was detected by real-time PCR targeting the invA gene (Malorny et al., 2003). Shigella sp. (virulent types) and/or E. coli EIEC was detected by real-time PCR targeting the ipaH (invasion plasmid antigen) gene (Theron et al., 2001). The detection and gene coding of all strains of $V$. cholerae was performed according to the procedures described by Le Roux and Van Blerk (2011). The water samples were analysed for the presence of Enterovirus and Norovirus according to methods described in Da Silva et al. (2007), Fuhrman et al. (2005) and Loisy et al. (2005). Analysis for protozoan parasitic (Giardia sp. and Cryptosporidium sp.) was carried out according to the USEPA 1623 method (U.S. Environmental Protection Agency, 1999).

\subsection{Metal analysis in raw water}

Water samples collected from the various sites were filtered through $0.45 \mu \mathrm{m}$ pore size Whatman GF/filters and stored in polyethylene bottles that had been prerinsed with dilute sulphuric acid (to $\mathrm{pH} 2.0$ ). All metal analyses were carried out according to standard methods (APHA, 1995) in an accredited analytical laboratory.

\subsection{Endocrine disrupting activity}

Endocrine disruption was measured in the water according to the protocol described in Wilson et al. (2004) using the T47D-KBluc reporter gene assay. This procedure, like most other bio-assays, is limited in that it is unable to detect prooestrogens (compounds that are converted to oestrogens in vivo), or to conclusively identify the causative chemical without chemical analysis. The assay only evaluates the ability of the combined chemicals to modulate the activity of oestrogendependent gene transcription. Adsorption, distribution, metabolism and elimination of these contaminants by the human body influence their toxicity, and these processes are also only partly mimicked in the bio-assays used in this study.

\subsection{Health risk assessments}

For non-carcinogenic toxic effects of heavy metals, a hazard quotient (HQ) was calculated, comparing the expected exposure to the agent to an exposure that was assumed not to be associated with toxic effects. For the oral exposure of humans to the consumption of contaminated water and plants, the Average Daily Dose (ADD), determined from the measured concentrations, was compared to a Reference Dose (RfD) as reported by the EPA. An HQ $<1$ was considered to be safe for a lifetime of exposure. The risk parameters, formulae and symbols are given in Table 2.

Microbial risk was calculated by entering the densities of the various pathogens (number of micro-organisms per litre) in the water samples into the risk model. This quantitative microbial risk assessment estimates the probability of infection based on the average pathogen dose (Haas et al., 1993). The calculation of probability of infection is a two-step process, comprising the combined probability of exposure and probability of infection. Incorporating some simplifying

Table 2

Risk assessment formula and parameters.

\begin{tabular}{|c|c|}
\hline Quantitative microbial risk assessment & Chemical risk assessment \\
\hline $\begin{array}{l}\text { Daily risk of infection } \\
\mathrm{Pi}=1-\left(1+\mathrm{d}\left(2^{1 / \mathrm{a}}-1\right) / \mathrm{N}_{50}\right)^{-\mathrm{a}} \\
\quad(\text { World Health Organization, 2001) } \\
\mathrm{P} i=1-(1+\mathrm{d} / \mathrm{b})^{-\mathrm{a}} \\
\quad(\text { Haas, } 1996) \\
\mathrm{P} i=1-\mathrm{e}^{-\mathrm{r} N} \\
\quad(\text { Haas, } 1996) \\
\text { where } \boldsymbol{P}_{\boldsymbol{i}} \text { is the probability (risk) of infection, } \boldsymbol{d} \text { the dose or exposure (number of } \\
\quad \text { organisms ingested based on consumption of } 1.2 \text { L of water/day), } \boldsymbol{\beta} \text { the parameter } \\
\quad \text { characterised by dose-response relationship, } \boldsymbol{\alpha} \text { the parameter characterised by } \\
\quad \text { dose-response relationship, } \boldsymbol{N}_{\mathbf{5 o}} \text { the median infectious dose, } \boldsymbol{r} \text { the parameter } \\
\text { characterised by dose-response relationship }\end{array}$ & $\begin{array}{l}\text { Non cancer toxic Effects, }(\mathrm{HQ}) \\
\mathrm{ADD}=C(m) \times \mathrm{IR} \times \mathrm{ED} \times \mathrm{EF} /(\mathrm{BW} \times \mathrm{AT}) \\
\mathrm{HQ}=\mathrm{ADD} / \mathrm{RfD} \\
\text { where HQ is theHazard Quotient, ADD the Average Daily Dose }\left(\mathrm{mg}^{-1} \mathrm{~kg}^{-1} \mathrm{day}^{-1}\right) \text {, } \\
\text { RfD the Reference Dose, } \mathbf{C}(\mathbf{m}) \text { the Contaminant concentration }\left(\mathrm{mg}^{-}, \mathbf{I R}_{\text {the }}\right. \\
\text { Ingestion rate }\left(\mathrm{kg} \mathrm{day}^{-1}\right), \mathbf{B W} \text { the Body Weight }(\mathrm{kg}) \text {, ED the Exposure duration } \\
\text { (years), EF the Exposure Frequency (days year }\end{array}$ \\
\hline Exposure conditions & Exposure parameters \\
\hline $\begin{array}{l}\text { Ratio of illness/infection } 0.7 \\
\text { Severity or Disease burden } 1.50 \times 10^{-3} \\
\text { Susceptibility fraction } 100 \text { percent }\end{array}$ & $\begin{array}{l}\text { Events per year } 350 \\
\text { BW } 70 \mathrm{~kg} \\
\text { Ingestion rate Water }\left(2 \mathrm{~L} \mathrm{day}^{-1}\right) \\
\text { Ingestion rate Plant }\left(0.1 \mathrm{~kg} \mathrm{day}^{-1}\right) \text { root } \\
\text { Plant }\left(0.2 \mathrm{~kg} \mathrm{day}^{-1}\right) \text { shoot }\end{array}$ \\
\hline $\begin{array}{l}\text { Reference dose }\left(\mathbf{m g}^{-\mathbf{1}} \mathbf{~ k g}^{-\mathbf{1}} \mathbf{d a y}^{-\mathbf{1}}\right)(\mathbf{E P A}) \\
\text { Aluminium } 1 \\
\text { Boron } 0.2 \\
\text { Manganese } 0.14\end{array}$ & $\begin{array}{l}\text { Selenium } 0.05 \\
\text { Vanadium } 0.009 \\
\text { Zinc } 0.3\end{array}$ \\
\hline
\end{tabular}


Table 3

Measured chemical and microbial concentrations from each of the Olifants River sampling sites.

\begin{tabular}{|c|c|c|c|c|c|c|c|c|c|c|c|c|c|c|c|}
\hline Risk Parameter & Site 1 & Site 2 & Site 3 & Site 4 & Site 5 & Site 6 & Site 7 & Site 8 & Site 9 & Site 10 & Site 11 & Site 12 & Site 13 & Site 14 & Site 15 \\
\hline \multicolumn{16}{|c|}{ Metal concentrations in water $\left(\mathrm{mg} \mathrm{L}^{-1}\right)$} \\
\hline Aluminium & 0.53 & 4.33 & 0.17 & 0.17 & 0.12 & 6.36 & 64 & 0.21 & 0.12 & - & - & 0.26 & 0.84 & 1.13 & 0.11 \\
\hline Boron & 0.036 & 0.119 & 0.04 & 0.046 & 0.021 & 0.211 & 0.053 & 0.037 & 0.052 & & & 0.013 & 0.013 & 0.039 & 0.013 \\
\hline Manganese & 0.68 & 3.39 & 0.03 & 0.01 & 0.01 & 4.7 & 27 & 0.2 & 1.13 & & & 0.06 & 0.07 & 0.24 & 0.02 \\
\hline Selenium & 0.005 & 0.006 & 0.006 & 0.006 & 0.007 & 0.016 & 0.005 & 0.007 & 0.012 & & & 0.006 & 0.013 & 0.012 & 0.008 \\
\hline Vanadium & 0.04 & 0.03 & 0.04 & 0.04 & 0.04 & 0.35 & 7.02 & 0.04 & 0.04 & & & 0.04 & 0.05 & 0.05 & 0.1 \\
\hline Zinc & - & 0.23 & - & - & - & 6.05 & 1.65 & - & 0.93 & - & - & - & - & - & - \\
\hline \multicolumn{16}{|c|}{ Metal concentrations in plants $\left(\mathbf{m g ~ k g}{ }^{-1}\right)$} \\
\hline Aluminium Root & 8546 & 18,031 & 10,977 & 6549 & 7531.5 & 47,996 & 11,111 & 8667 & 10,333 & & & 10,067 & & & \\
\hline Aluminium Shoot & 264.5 & 345.00 & 136 & 80 & 360 & 3961 & 640 & 1427 & 199 & & & 3904 & & & \\
\hline Manganese Root & 513 & 629 & 1820 & 683 & 2376.5 & 460 & 368.5 & 2572 & 411 & & & 253 & & & \\
\hline Manganese Shoot & 139 & 223.00 & 55 & 44 & 153 & 237.5 & 533.5 & 293.5 & 58 & & & 104 & & & \\
\hline Zinc Root & 63.5 & 56 & 84 & 34 & 195.5 & 516 & 187.5 & 172 & 290 & & & 47.5 & & & \\
\hline Zinc Shoot & 46 & 40.00 & 28 & 27 & 58 & 235 & 51.5 & 57.5 & 45 & & & 43.5 & & & \\
\hline Cadmium Root & & 0.7 & & & & 0.5 & & & 0.5 & & & 0.9 & & & \\
\hline \multicolumn{16}{|c|}{ Microbial pathogen concentrations (counts per $100 \mathrm{~mL}$ of water) } \\
\hline E. coli (*)average (MPN per $100 \mathrm{~mL}$ ) & 428 & 226 & 358 & 302 & 512 & 35,688 & & 14,366 & 11,466 & 1881 & 994 & 170 & & & \\
\hline Salmonella sp percent detected & 1 & & & & & 4 & & 4 & 3 & 2 & 2 & & & & \\
\hline Shigella percent detected & 0 & & & & & 3 & & 2 & 3 & 0 & 0 & & & & \\
\hline Vibrio sp. percent detected & 0 & & & & & 1 & & 2 & 5 & 3 & 3 & & & & \\
\hline Norovirus & 0 & & & & & 162 & & 48 & 830 & 0 & 0 & & & & \\
\hline Enteric viruses & 0 & & & & & 1620 & & 0 & 2800 & 0 & 0 & & & & \\
\hline Giardia sp. & 0.5 & & & & & 0 & & 0 & 0.25 & 7.5 & 1 & & & & \\
\hline Cryptosporidium sp. & 0 & & & & & 0 & & 0 & 0.25 & 1.2 & 0.25 & & & & \\
\hline \multicolumn{16}{|l|}{ Oestrogen activity (equivalents $\mathrm{ng} \mathrm{L}^{-1}$ ) } \\
\hline Estradiol (EEQ) & 0.04 & & & 0.66 & 1.42 & 8.88 & & 0.99 & 8.27 & 2.42 & 0.79 & 0.14 & & & \\
\hline STDEV & 0.03 & - & - & 0.22 & 0.12 & 2.31 & - & 0.36 & 2.18 & 0.27 & 0.21 & 0.06 & - & - & - \\
\hline
\end{tabular}

assumptions in the relationship between numbers of organisms ingested and infection, a simple dose-response relationship referred to as the Beta Poisson was derived. This holds when $\beta \geq 1$ and $\alpha \leq \beta$. The risk parameters, formulae and symbols for the microbial health risk assessment are given in Table 2 . The pathogen parameters $\left(N_{50}, \alpha, \beta\right.$ and $r$ ) for the pathogens investigated in this study were taken from Haas et al. (1993), Strachan et al. (2005), Fankem Mingo (2008), Haas et al. (1999) and Teunis et al. (1996).

\section{Results and discussion}

\subsection{Health risk assessment for exposure to metals}

The riparian plant species collected for analysis are grazed by livestock destined for human consumption. The average metal concentrations in the plant samples provide an estimate of metal concentrations that might be found in plants edible by humans. The USEPA (U.S. Environmental Protection Agency, 1992) notes that the risk of exposure to metals through direct or indirect plant consumption is high if the plant roots and shoots, in particular, are consumed. The prediction of toxicity from dietary exposure to inorganic metals is complicated by the wide variation in the bioavailability and toxicity of metals. Further, the exposure of a specific community to a contaminant requires knowledge of dietary preferences, trophic structure of the community, and ingestion and absorption rates. The most common route of metal uptake in plants is from the soil through the roots. Ions and organic molecules contact roots via the transpiration stream and diffusive and microbe-facilitated transport. The plant species sampled showed overall increased aluminium and manganese absorption in their roots compared to their shoots (Table 3). Restricted translocation of metals from roots to shoots is common and believed to be a strategy to avoid high metal concentrations in photosynthetic tissue, where total chlorophyll concentrations and plant growth are negatively affected (Abdel-Basset et al., 1995; Manios et al., 2003 and Bragato et al., 2006).

The risk parameters given in Table 2 were used to determine the resulting risk quotients for each of the sampling sites in Fig. 2.
The average individual metal concentration measured in the plant and water samples was used to determine the health risk, expressed as a hazard quotient (HQ), posed by each of the metals (Fig. 2). Aluminium and manganese exposure presented the highest risk in plants at all of the sampling sites. The elevated aluminium risk is due to the acidity which mobilises aluminium into the water (Krewski et al., 2007). Although the region is known to have a more acidic natural geology, acidification of the soil is intensified by mining practices, especially acid mine drainage (Winterbourn et al., 2000; Younger et al., 2002). The impacts of mining on the aluminium health risks associated with the consumption of plants in the region are especially evident at sites 2 and 6 . The most profound known adverse health links ascribed to Al toxicity are bone diseases and neurological disorders (SuárezFernández et al., 1999; Bondy, 2010). Premature infants have been found to be the most sensitive to $\mathrm{Al}$ exposure (Hellström et al., 2008; Driscoll et al., 1997). Aluminium is exponentially accumulated in the body with ageing and can trigger excess apoptosis (cell death) (Ganrot, 1986) which impairs certain cellular immune responses (Prolo et al., 2007). These impacts are of special concern in South Africa, where the elderly and HIV infected persons already suffer from compromised immune systems making them even more vulnerable to other serious infections (Hellström et al., 2008). According to the 2008 National Health Survey, 10.9 percent of 50 million South Africans are HIV-positive, of which 16.9 percent are between the ages of 25 and 49 (Statistics South Africa, 2010).

The health risk posed by manganese is widespread, with the Klein Olifants River between sites 5 and 8 posing the highest risk. The overall occurrence of this elevated health risk is likely due to the atmospheric deposition of manganese (fossil fuels and coalfired power stations) on soil and water (Lytle et al., 1995) and from acid mine drainage. Exposure to excess manganese may cause Parkinson-like symptoms (Gerber et al., 2002; Erikson and Aschner, 2003), infertility in mammals and malfunction of the immune system (Vartanian et al., 1999). 


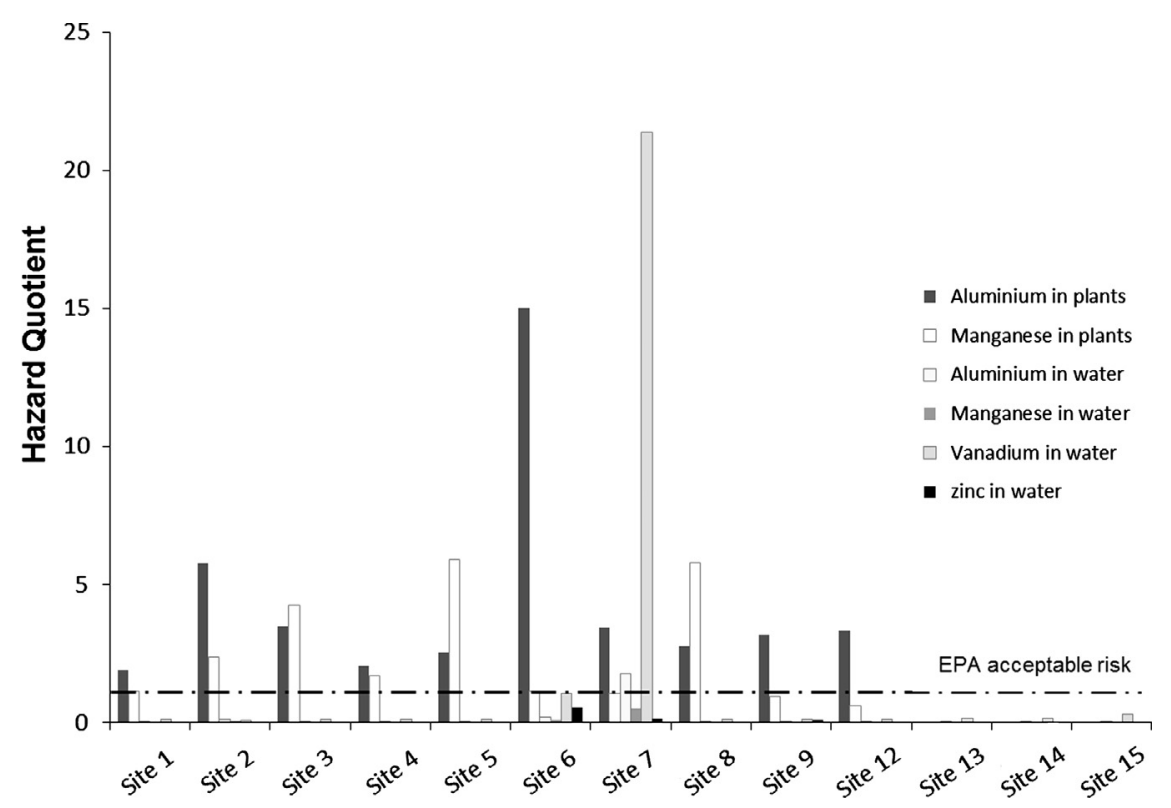

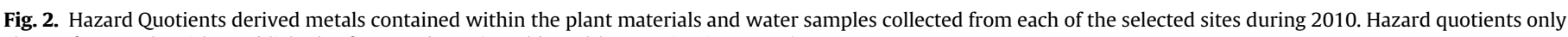
shown for metals with established reference doses (World Health Organization, 2010).

From the HQ determined for metal concentrations (Table 3) i n indicating that the upper Olifants River system is heavily conwater samples collected from each of the sampling sites, only sites 6 taminated by faecal-derived microbes. The E. coli counts were and 7 showed increased health risks due to vanadium and aluminium strongly related to the population density, being greater at sites concentrations (Fig. 2). The most likely source of the vanadium is a closer to larger cities such as Emahlahleni/Witbank and Middelvanadium processing plant in this area. While elemental vanadium burg. Faecal contamination at sites 6, 8 and 9 is largely attributed does not occur in nature, vanadium com-pounds are found in fossil to the runoff from informal settlements as well as the discharge fuels and exist in over 50 different mineral ores. The EPA reference from wastewater treatment plants (WWTPs) in close proximity to dose (RfD) for vanadium com-pounds (most commonly vanadium each of the sampling sites. The E. coli counts at sites 10 and 11 are pentoxide, $\mathrm{V}_{2} \mathrm{O}_{5}$ ) i s $\quad 0.009 \mathrm{mg}^{-1} \mathrm{~kg}^{-1} \mathrm{~d}^{-1}$ with an uncertainty likely due to runoff from upstream cattle feedlots and livestock of 100 . Uncertainty factors provide a level of reassurance of safety farming land uses.

from the harmful effects of exposure to chemicals in the face of limited information. A factor of 100 is considered a relatively "safe" measure of uncertainty (Interdepartmental Group on Health Risks from Chemicals, 2003). The RfD was set to provide protection for unborn children and neonates (IRIS, 1996). Vanadium in $\mathrm{V}_{2} \mathrm{O}_{5}$ has been found to change hair cystine levels, but has not yet been associated with adverse health effects (U.S. Environmental Protection Agency, 2011).

The health risk associated with aluminium in water is greater at site 7, where the impact of acidic mining tailings and decanting coal mines is most pronounced. The HQ determined for boron and selenium in water and cadmium and zinc in plants were negligible $(<0.5)$.

\subsection{Microbial health risk assessment}

\subsubsection{Occurrence of faecal indicators}

Indicator bacteria such as E. coli are valuable tools to determine the occurrence and extent of faecal contamination in water sources. These organisms act as indicators of faecal pollution, and have similar fate, transport and survival characteristics to the related pathogens they represent (Edberg et al., 2000). No single indicator is accurate for the full spectrum of water-borne pathogens that may be present in a water source. Viruses, protozoan parasites and bacteria all behave differently in the aquatic environment, where inter- and intra-group differences abound. For this reason, seven specific human pathogens (representing all three major groups) were enumerated. The microbial counts for E. coli and various pathogens are given in Table 3.

From the $E$. coli results presented in Fig. 3, it can be seen that sites $6,8,9$ and to a lesser extent site 10, had high counts of E. coli,

\subsubsection{Occurrence of pathogens}

The risk parameters, formulae and symbols for the microbial health risk assessment are given in Table 2 and the resulting probabilities of infection (Pi) are given in Fig. 4. Water from sites 1, $6,8,9,10$ and 11 was subjected to analysis for a range of pathogens. The results (Table 3 ) identify site 9 as the most contaminated site, and site 1 as the least contaminated. Sites 6, 8, 10 and 11 all exhibit the occurrence of pathogenic organisms. Salmonella sp. was found at all six sites, $V$. cholerea (non-enter-otoxigenic) at five sites $(6,8$, 9, 10 and 11) and Shigella sp. at three sites (6, 8 and 9). The protozoan parasites Giardia and Cryptospor-idium, generally associated with livestock farming and domesti-cated animals (Thompson et al., 2008; Olson et al., 1997), were detected at site 9, 10 and 11 , the latter two sites located immedi-ately down-stream of cattle feedlots.

The process of risk characterisation combines the exposure assessment with the dose-response models to provide a likelihood of adverse effect (in this case the probability of infection). The data reported in Table 3 were used to calculate the probability of infection for each of the listed pathogens. The result is given in Fig. 4 whereas the risk of infection by Salmonella was low $(\sim 0.1$ percent), that for Shigella and $V$. cholerae ranged between 1 percent and 6 percent. Of greatest risk to water users, however, are Norovirus (ranging between 6 percent and 14 percent) and Giardia the latter posing a 13.8 percent risk at a single site (site 10) situated below a cattle feedlot.

The average risk of infection for each of the enumerated pathogens detected was summed to give an indication of the combined microbial risk associated with each sampling site. Water 


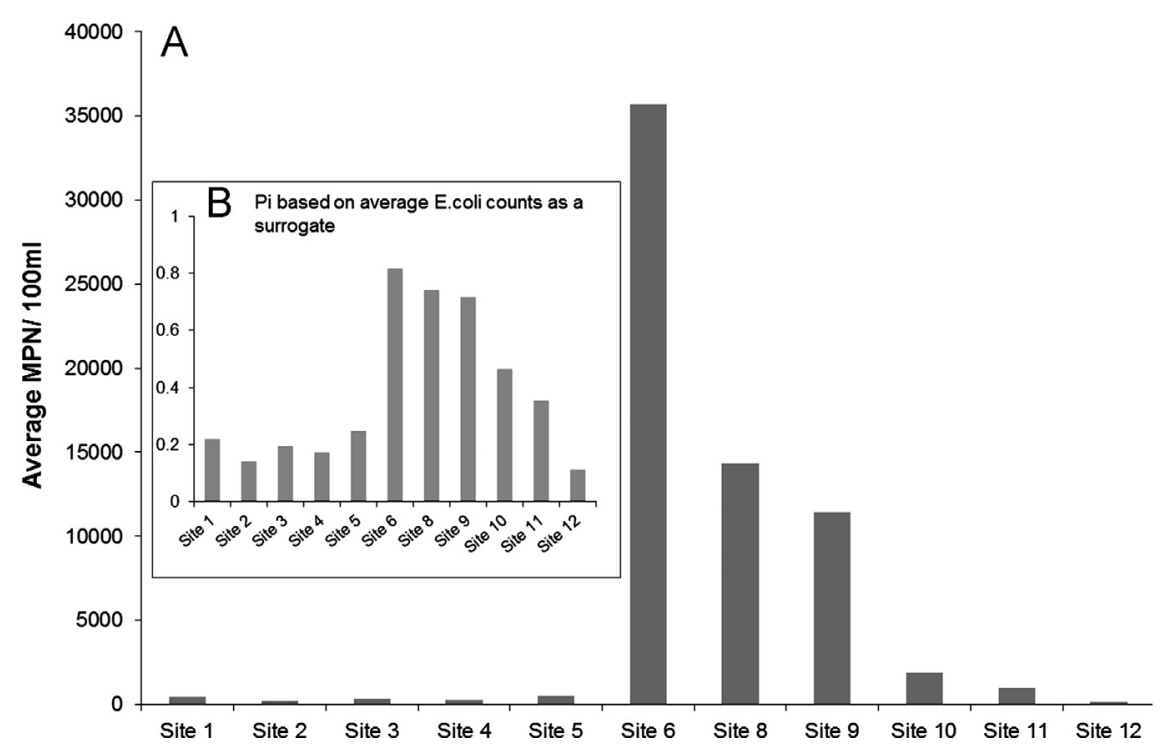

Fig. 3. (a) The average MPN of E. coli per $100 \mathrm{ml}$ used as faecal indicator for each of the sampling sites and (b) Pi, the probability of infection, of $E$. coli based on average $E$. coli counts as surrogate.

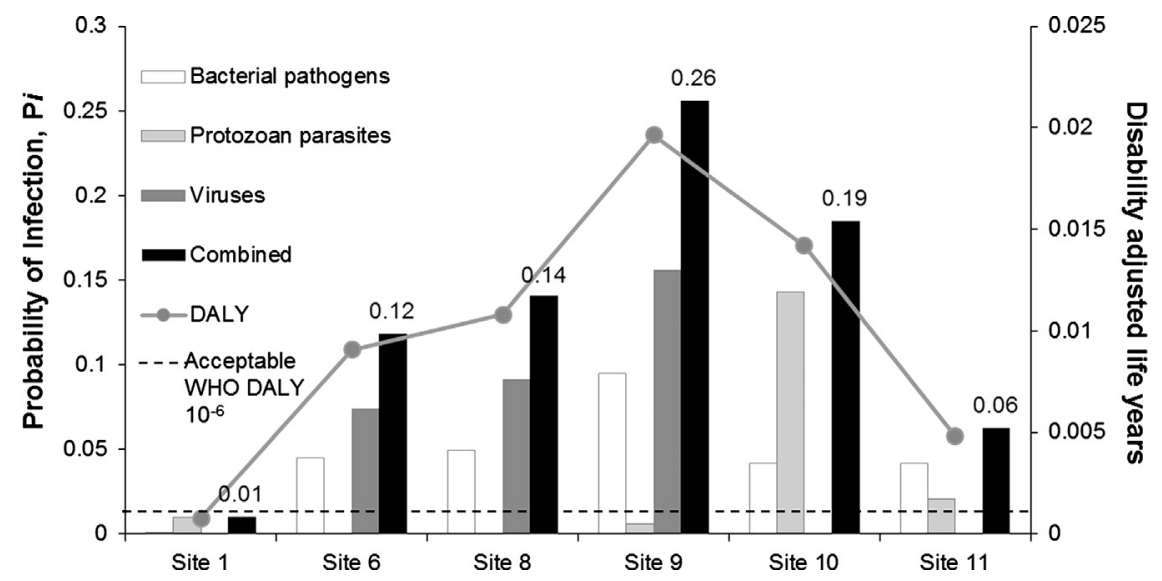

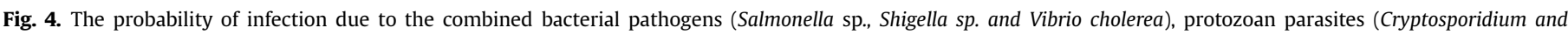

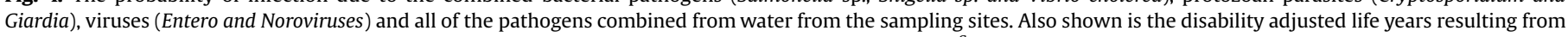
consumption of untreated water from the selected sampling sites and the acceptable WHO DALY of $10^{-6}$.

from site 9 resulted in the highest risk of infection, followed by sites 10,8 and 6 with risks ranging from 26 percent probability to 12 percent probability based on very conservative single event exposure consumptions. The presence of Norovirus was responsible for the high risk posed to local communities, followed by the bacterial pathogens Vibrio and Shigella.

The disability-adjusted life year (DALY) is a measure of overall disease burden, and represents a measure of the suffering caused by an illness. It is the primary metric used by the World Health Organization to assess the global burden of disease (World Health Organization, 2001). The DALY combines both mortality in terms of years of life lost (YLL), and morbidity in terms of years lived with a disability (YLD), into a single value. The disability severity is assigned a weight ranging from zero (perfect health) to one (representing the most severe disability or death). One DALY per million people a year roughly equates to one death per 100,000 in a 70-year lifetime (the benchmark often used in chemical risk assessments) (World Health Organization, 2004). The DALY value associated with each sampling site was determined using the combined probability of infection from the enumerated pathogens, assuming a 20 percent susceptibility fraction. The susceptibility fraction was used as a conservative measure, assuming 80 percent immunity against the combined risk posed by the enumerate pathogens. The DALYs determined for the sampling sites was significantly higher than the World Health Organization recommended DALY of 0.000001 or 1 in a million (Fig. 4).

DALYs varied from 1 in 1000 (0.00077) for site 1 to approximately 2 in $100(0.02)$ for site 9 . As in the case of the risk calculations, these values are an underestimate of the DALYs, indicating the severe impact that can be anticipated from ingesting only a small quantity $(100 \mathrm{~mL})$ of untreated river water. The results show that the anticipated disability-adjusted life years resulting from drinking untreated river water are in the order of four orders of magnitude greater than what is considered acceptable by the WHO (World Health Organization, 2001) ( Fig. 4).

\subsubsection{Occurrence of endocrine disrupters}

There is no standardised method or guideline to assess human health risks associated with endocrine disrupting chemicals (World Health Organization, 2004). However, an approach similar to toxic equivalency factors is used for hormones and their activity in water, and can be expressed in terms of equivalency factors or quotients (e.g. estradiol equivalent quantity or EEQ). A value above the EEQ a so-called trigger value, serves as an indicator that more detailed EDC testing is required. The oestrogenic activity in 


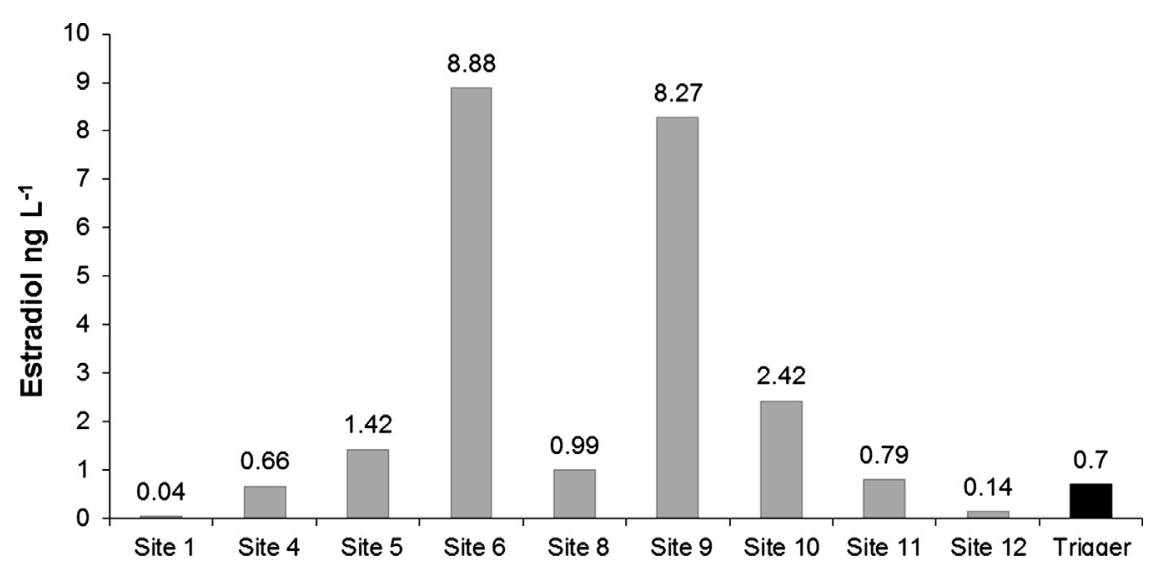

Fig. 5. Oestrogenic activity of water samples collected from the Olifants River sites, compared to the trigger value of $0.7 \mathrm{ng} \mathrm{L}^{-1}$ determined by Genthe et al. (2009).

environmental samples was determined with the T47D-KBluc gene bioassay. The trigger value of $0.7 \mathrm{ng} \mathrm{L}^{-1}$ was based on the acceptable daily intake (ADI) of $200 \mathrm{pg}^{-1} \mathrm{~kg}^{-1} \mathrm{~d}^{-1}$ (as opposed to 50 $\mathrm{ng}^{-1} \mathrm{~kg}^{-1} \mathrm{~d}^{-1}$ suggested by the WHO (World Health Organization, 2004)) to compensate for sensitive subpopulations, individual variation, percentage availability and a safety factor of 1000 (Genthe et al., 2009).

Water samples may comprise a complex mixture of chemicals with possible (anti)-androgenic and (anti)-oestrogenic activity, as well as other chemicals not measured, that could affect the outcome of the assay. It should therefore be noted that EEQs are only rough estimates, as the complexity of the sample, $\mathrm{pH}$, extraction procedure and the nature of the assay (i.e. a biological system) might all have an influence on the results. The EEQ levels for the sampling sites are given in Table 3 and illustrated in Fig. 5.

Sampling sites 5, 6, 8, 9 and 10 EEQs measured oestrogen activity above the trigger value suggested for healthy drinking water (Genthe et al., 2009), if this river water were to be used untreated for domestic purposes. Although site 10 tested positive for oestrogenic activity, undiluted $(1 \times)$ and higher concentrations of site 10 suppressed the activity of $0.1 \mathrm{nM} E_{2}$. Possible explanations are the nature of the sample/ $E_{2}$ curve (e.g. non-monotonic dose-response curve), the presence of anti-oestrogenic substances in the sample or the presence of cytotoxic compounds in the sample mixture. A test for cytotoxicity (e.g. MTT test) in the site 10 sample would be required to reject this as a cause for the T47DKBluc assay result. Similar results were obtained with all the other samples when concentrated $10 \times$ or higher (Fig. 5).

Sites 6 and 9 showed markedly higher EEQ levels than the other sites, indicating a significant threat of potential endocrine disrupting health problems. Sites 6 and 9, are located close to an informal settlement and a WWTW proximal to a large city. The high oestrogenic activity and possible EDC levels are therefore likely due to untreated or insufficiently treated sewage effluent.

\section{Conclusions}

Water and plant samples collected from 15 sites on the Olifants River were analysed for faecal contamination, seven specific human pathogens representing bacterial, protozoan and viral contamination, and heavy metals indicative of bioaccumulation in plants. The results indicate the following:

- portions of the Upper Olifants River catchment are highly contaminated with faecal indicator bacteria with associated microbial pathogens, and a quantitative microbial risk assessment showed that the polluted waters pose an unacceptably high risk to water users;

- a heavy metal health risk assessment indicated that aluminium and manganese accumulated in plants pose a significant noncancerous health risk, whereas water of the Klip Spruit close to a vanadium processing plant returned a vanadium health risk factor 20-fold of what is considered safe for human consumption;

- oestrogen activity resulting from endocrine disrupting compounds in the water samples is above the trigger value at 60 percent of the sites monitored and was the highest at sites in the vicinity of wastewater treatment plants; and

- the calculated possible health impacts associated with each of the hazardous materials cannot be viewed in isolation.

The combined microbial impacts on human health at site 6 , for example, ascribe a 12 percent probability of infection by a pathogen and a DALY of approximately 1 in 100 from a single dose. Combined with the oestrogen activity at this site, which is over 10 times higher than the recommended trigger value, the water from this site is likely to cause adverse health effects in the surrounding communities. The health situation at this site is exasperated by the high occurrence of aluminium and manganese in the water and surrounding plant life, which are known to compromise the immune system. This makes the exposed community even more susceptible to the $E$. coli, pathogen microbes and endocrine disrupting chemicals contained in these contaminated waters.

Faecal contamination with associated microbial pathogens and oestrogenic activity of the collected water samples could be tracked back to inadequate wastewater treatment, agricultural runoff (cattle feedlots) or sewage effluents. Aluminium contamination across the region in plants is partially caused by acidification of the soil by mining practices, which leach aluminium from the soil into the water, creating an uptake pathway for plants. From the combined results of the risk assessment, it is concluded that the combination of untreated sewage, mining and industrial practices severely compromise the water quality in the Olifants River, and have the potential to seriously impact on human health, especially in lower income communities that make direct use of untreated river water.

\section{Acknowledgments}

This study was supported financially by the Olifants River Forum. 


\section{References}

APHA, 1995. Standard Methods for the Examination of Water and Wastewater, 19th ed. American Public Health Association, Washington DC.

Abdel-Basset, R., Issa, A.A., Adam, M.S., 1995. Chlorophyllase activity: effect of heavy metals and calcium. Photosynthetica 31, 421-425.

Andersson, Y., Bohan, P., 2001. Disease surveillance and waterborne outbreaks. In: Fewtrell, L., Bartram, J. (Eds.), Water Quality: Guidelines, Standards and Health. Assessment of Risk and Risk Management for Water-Related Infectious Disease. IWA Publishing, London, pp. 116-133.

Aneck-Hahn, N., Bornman, M.S., Jager, C., 2009. Oestrogenic activity in drinking waters from a rural area in the Waterberg District, Limpopo Province, South Africa. Water SA 35, 245-251.

Ashton, P.J., 2010. The demise of the Nile crocodile (Crocodylus niloticus) as a keystone species for aquatic ecosystem conservation in South Africa: the case of the Olifants River. Aquat. Conserv.: Mar. Freshwat. Ecosyst. 20, 489-493.

Borneman, M.S., Van Vuren, J.H.j. Bouwman, H., De Jager, C., Genthe, B., Barnhoorn, I.E.J., 2007. Endocrine Disruptive Activity and the Potential Health Risk in an Urban Nature Reserve. Water Research Commission, Pretoria, South Africa 1505/1/07.

Bragato, C., Brix, H., Malagoli, M., 2006. Accumulation of nutrients and heavy metals in Phragmites australis (Cav.) Trin. ex Streudel and Bolboschoenus maritimus (L.) Palla in a constructed wetland of the Venice Lagoon watershed. Environ. Pollut. 144, 967-975.

Crisp, T.M., Clegg, E.D., Cooper, R.L., Wood, W.P., Anderson, D.G., Baetcke, K.P., Hoffmann, J.L., Morrow, M.S., Rodier, D.J., Schaeffer, J.E., 1998. Environmental endocrine disruption: an effects assessment and analysis. Environ. Health Perspect. 106, 11-56.

Da Silva, A.K., Le Saux, J.C., Parnaudeau, S., Pommepuy, M., Elimelech, M., Le Guyader, F.S., 2007. Evaluation of removal of noroviruses during wastewater treatment, using real-time reverse transcription-PCR: different behaviors of genogroups I and II. Appl. Environ. Microbiol. 73, 7891-7897.

Department of Water Affairs, South Africa, 2011. The Green Drop Report. Waste

Water Quality Management Performance. DWA.

Driscoll, W.R., Cummings, J.J., Zorn, W., Bishop, N.J., Morley, R., 1997. Aluminum toxicity in preterm infants. N. Engl. J. Med. 337, 1090-1091.

Dyer, S.D., Belanger, S.E., 1999. Determination of the sensitivity of macroinvertebrates in stream mesocosms through field-derived assessments. Environ. Toxicol. Chem 18, 2903-2907.

Edberg, S.C., Rice, E.W., Karlin, R.J., Allen, M.J., 2000. Escherichia coli: the best biological drinking water indicator for public health protection. J. Appl. Microbiol. 88, 106-116.

Erikson, K.M., Aschner, M., 2003. Manganese neurotoxicity and glutamate-GABA interaction. Neurochem. Int. 43, 475-480.

Fankem Mingo, S.L., 2008. The Role of Fomites in the Transmission of Norovirus.

Ph. D. Dissertation.

Field, K.G., Samadpour, M., 2007. Fecal source tracking, the indicator paradigm, and managing water quality. Water Res. 41, 3517-3538.

Fuhrman, J.A., Liang, X., Noble, R.T., 2005. Rapid detection of enteroviruses in small volumes of natural waters by real-time quantitative reverse transcriptase PCR. Appl. Environ. Microbiol. 71, 4523-4530.

Ganrot, P.O., 1986. Metabolism and possible health effects of aluminum. Environ. Health Perspect. 65, 363-441.

Genthe, B., Steyn, M., Aneck-Hahn, N.H., van Zijl, C., de Jager, C., 2009. The Feasibility of a Health Risk Assessment Framework to Derive Guidelines for Oestrogen Activity in Treated Drinking Water. Water Research Commission, Pretoria, South Africa WRC 1749/1/02.

Gerber, G., Leonard, A., Hantson, P., 2002. Carcinogenicity, mutagenicity and teratogenicity of manganese compounds. Crit. Rev. Oncol. 42, 25-34.

Haas, C.N., Rose, J.B., Gerba, C., Regli, S., 1993. Risk assessment of virus in drinking water. Risk Anal. 13, 545-552.

Haas, C.N., Rose, J.B., Gerba, C.P., 1999. Quantitative Microbial Risk Assessment. John Wiley \& Sons Inc, New York.

Hellström, H.O., Michaëlsson, K., Mallmin, H., Mjöberg, B., 2008. The aluminium content of bone, and mortality risk. Age Ageing 37, 217-220.

Hobbs, P., Oelofse, S.H.H., Rascher, J., 2008. Management of environmental impacts from coal mining in the upper Olifants River catchment as a function of age and scale. Int. J. Water Res. 24, 417-431.

IRIS, 1996. Vanadium pentoxide. Integrated Risk Inf. Syst.

Interdepartmental Group on Health Risks from Chemicals, 2003. Uncertainty factors. Their use in human health risk assessments by the UK government. IGHRC.

Krewski, D., Yokel, R.A., Nieboer, E., Borchelt, D., Cohen, J., Harry, J., Kacew, S., Lindsay, J., Mahfouz, A.M., Rondeau, V., 2007. Human health risk assessment for aluminium, aluminium oxide, and aluminium hydroxide. J. Toxicol. Environ. Health Pt. B 10, 1-269.

Ksoll, W.B., Ishii, S., Sadowsky, M.J., Hicks, R.E., 2007. Presence and sources of fecal coliform bacteria in epilithic periphyton communities of Lake Superior. Appl. Environ. Microbiol. 73, 3771-3778.

Le Roux, W.J., Van Blerk, G.N., 2011. Use of a high resolution melt real-

timpolymerase chain reaction (PCR) assay for the environmental monitoring of Vibrio cholerae. Afr. J. Microbiol. Res. 5, 3520-3526.
Loisy, F., Atmar, R., Guillon, P., Le Cann, P., Pommepuy, M., Le Guyader, F., 2005. Real-time RT-PCR for norovirus screening in shellfish. J. Virol. Methods 123, $1-7$.

Lytle, C.M., Smith, B.N., McKinnon, C.Z., 1995. Manganese accumulation along

Utahroadways: a possible indication of motor vehicle exhaust pollution. Sci. Total Environ. 162, 105-109.

Malorny, B., Hoorfar, J., Bunge, C., Helmuth, R., 2003. Multicenter validation of the analytical accuracy of Salmonella PCR: towards an international standard. Appl. Environ. Microbiol. 69, 290-296.

Manios, T., Stentiford, E.I., Millner, P.A., 2003. The effect of heavy metals accumulation on the chlorophyll concentration of Thypa latifolia plants, growing in a substrate containing sewage sludge compost and watered with metalliferous water. Ecol. Eng. 20, 65-74.

Miyamoto, J., Burger, J., 2003. Implications of endocrine active substances for humans and wildlife; reports from a SCOPE/IUPAC project. Pure Appl. Chem. 75, 1617-2615.

Nagajyoti, P., Lee, K., Sreekanth, T.V.M., 2010. Heavy metals, occurrence and toxicityfor plants: a review. Environ. Chem. Lett. 8, 199-216.

Oberholster, P., Myburgh, J., Ashton, P., Botha, A.M., 2010. Responses of phytoplankton upon exposure to a mixture of acid mine drainage and high levels of nutrient pollution in Lake Loskop, South Africa. Ecotoxicol. Environ. Saf. 73, 326-335.

Oberholster, P.J., 2011. Using Epilithic Filamentous Green Algae Communities

as Indicators of Water Quality in the Headwaters of Three South African River Systems during High and Medium Flow Periods, in Zooplankton and Phytoplankton. Nova Science Publishers, USA.

Olson, M.E., Thorlakson, C.L., Deselliers, L., Morck, D.W., McAllister, T.A., 1997. Giardia and Cryptosporidium in Canadian farm animals. Vet. Parasitol. 68, 375-381.

Pedersen, J.A., Yeager, M.A., (Mel) Suffet, IH, 2003. Xenobiotic organic compounds in runoff from fields irrigated with treated wastewater. J. Agric. Food Chem. 51, 1360-1372.

Prolo, P., Chiappelli, F., Grasso, E., Rosso, M.G., Neagos, N., Dovio, A., Sartori, M.L., Perotti, P., Fantò, F., Civita, M., 2007. Aluminium blunts the proliferative response and increases apoptosis of cultured human cells: putative relationship to alzheimer's disease. Bioinformation 2, 24-27.

Rahman, M., Yanful, E., Jasim, S., 2009. Occurrences of endocrine disrupting compounds and pharmaceuticals in the aquatic environment and their removal from drinking water: challenges in the context of the developing world Desalination 248, 578-585.

Rashed, M., 2010. Monitoring of contaminated toxic and heavy metals, from mine tailings through age accumulation, in soil and some wild plants at Southeast Egypt. J. Hazard. Mater. 178, 739-746.

Robins, J.C., Marsit, C.J., Padbury, J.F., Sharma, S.S., 2011. Endocrine disruptors, environmental oxygen, epigenetics and pregnancy. Front. Biosci. (Elite edition) $3,690-700$.

Schachtschneider, K., Muasya, M., Somerset, V., 2010. Are indigenous sedges useful for phytoremediation and wetland rehabilitation? CSIR 3rd Biennial Conference 2010. Science Real and Relevant. CSIR International Convention Centre, Pretoria, South Africa, 30 August-01 September 2010.

Slabbert, J.L., Venter, E.A., Moletsane, M., Van Wyk, J.H., Blaise, C., Aneck-Hahn, N.H 2007. An Investigation of the Estrogenic Activity in Water From Selected Drinking Water Treatment Processes. Water Research Comission Report WRC 1532/1/07.

Soto, A.M., Sonnenschein, C., 2010. Environmental causes of cancer: endocrine disruptors as carcinogens. Nat. Rev. Endocrinol. 6, 363-370.

Statistics South Africa, 2010. Mortality and Causes of Death in South Africa: Findings From Death Notification, 2008. StatSA, on-line.

Strachan, N.J.C., Doyle, M.P., Kasuga, F., Rotariu, O., Ogden, I.D., 2005. Dose response modelling of Escherichia coli 0157 incorporating data from foodborne and environmental outbreaks. Int. J. Food Microbiol. 103, 35-47.

Suárez-Fernández, M.B., Soldado, A.B., Sanz-Medel, A., Vega, J.A., Novelli, A., Fernández-Sánchez, M.T., 1999. Aluminum-induced degeneration of astrocytes occurs via apoptosis and results in neuronal death. Brain Res. 835, 125-136.

Ternes, T.A., Stumpf, M., Mueller, J., Haberer, K., Wilken, R.D., Servos, M., 1999 Behavior and occurrence of estrogens in municipal sewage treatment plants-I. Investigations in Germany, Canada and Brazil. Sci. Total Environ. 225, 81-90.

Teunis, P.F.M. Vvan der Heijden, O.G., Vvan der Giessen, J.W.B., Havelaar, A.H., 1996. The dose-response relation in human volunteers for gastro-intestinal pathogens. Rijksinstituut voor Volksgezondheid en Milieu RIVM Technical Report 284550002.

Theron, J., Morar, D., Du Preez, M., Brözel, V.S., Venter, S.N., 2001. A sensitive seminested PCR method for the detection of Shigella in spiked environmental water samples. Water Res. 35, 869-874.

Thompson, R., Palmer, C.S., O'Handley, R., 2008. The public health and clinical significance of Giardia and Cryptosporidium in domestic animals. Vet. J. 177, 18 25.

U.S. Environmental Protection Agency, 1987. Risk Assessment Guidelines of 1986 USEPA EPA/600/8-87/045.

U.S. Environmental Protection Agency, 1992. Guidelines for Exposure Assessment. USEPA EPA/600/Z-92/001.

U.S. Environmental Protection Agency, 1999. Method 1623: Cryptosporidium and Giardia in Water by Filtration/IMS/FA. USEPA EPA 821-R-99-006.

U.S. Environmental Protection Agency, 2011. Toxicological review of vanadium pentoxide (V2O5). USEPA EPA/635/R-11/004A. 
Vartanian, J.P., Sala, M., Henry, M., Wain-Hobson, S., Meyerhans, A., 1999. Manganese cations increase the mutation rate of human immunodeficiency virus type 1 ex vivo. J. Gen. Virol. 80, 1983-1986.

Watson, R.M., Crafford, D., Avenant-Oldewage, A., 2012. Evaluation of the fish health assessment index in the Olifants River system, South Africa. Afr. J. Aquat. Sci. 37, 235-251.

Wilson, V.S., Bobseine, K., Gray Jr, L.E., 2004. Development and characterisation of a cell line that stably expresses an oestrogen-responsive luciferase reporter for the detection of oestrogen receptor agonist and antagonists. J. Toxicol. Sci. 81, 69-77.

Winterbourn, M., McDiffett, W., Eppley, S., 2000. Aluminium and iron burdens of aquatic biota in New Zealand streams contaminated by acid mine drainage: effects of trophic level. Sci. Total Environ. 254, 45-54.
World Health Organization, 2001. Water Quality: Guidelines, Standards and Health. Assessment of Risk and Risk Management for Water Related Infectious Disease. WHO.

World Health Organization, 2004. The World Health Report 2004. Changing History. WHO.

World Health Organization, 2010. Human Health Risk Assessment Toolkit. WHO.

World Health Organization and International Program on Chemical Safety, 2002. Global Assessment of the State-of-the-Science of Endocrine Disruptors. WHO/ IPCS.

Younger, P.L., Banwart, S.A., Hedin, R.S., 2002. Mine Water: Hydrology, Pollution, Remediation. Springer, Kluwer Academic, London. 